\title{
Virtuaalipeliympäristö strategisesti tehokkaan yhteistyön harjoittajana
}

\begin{abstract}
$+y$
Kirjoittaja tutki väitöstutkimuksessaan peliympäristöjä yhteisöllisen oppimisen rikastajina. Hänen mukaansa peliympäristössä syntyy vahva yhteinen tila, joka vahvistaa keskinäistä vuorovaikutusta ja yhteisöllistä oppimista. Hänen käyttämiään peliympäristöjä olivat eScape ja Gate for Collaboration. Tutkijan mukaan peliympäristö motivoi ja helpottaa hajautetuissa ryhmissä vaikeidenkin asioiden käsittelyä.
\end{abstract}

USKOMUS SIITÄ, että paras tiimi syntyy laittamalla alansa parhaat asiantuntijat yhteen, elää vahvana. Menestystiimin resepti on kysymyksenä yhä ajankohtaisempi innovaatioita ja tehokkuutta hakevassa maailmassamme. Kohtaamiemme ongelmien ollessa yhtä monimutkaisempia, työtä tehdään moniammatillisissa ja poikkitieteellisissä tiimeissä parhaimman tietopohjan varmistamiseksi (Prins 2010). Yhdessä toimiminen vaatii kuitenkin muitakin taitoja kuin sisältöosaamista ja onnistumisen kannalta ratkaisevassa asemassa onkin osallistujen välinen sosiaalinen vuorovaikutus (Barron 2003), jonka kautta ongelmia pohditaan ja rajataan yhdessä. Onkin ajankohtaista kysyä opimmeko tehokkaaseen vuorovaikutukseen vain tekemällä töitä yhdessä? (Bransford et al. 2006).

Yhteisöllisen oppimisen ja asiantuntijuuden tutkimukset ovat useaan otteeseen osoittaneet, että oman alansa sisältöasiantuntijat eivät välttämättä ole asian- tuntijoita siinä, miten heittäytyä yhteisölliseen tiedonrakenteluun toisten kanssa (Salas, Rosen, Burke, Goodwin, \& Fiore 2006). Oppiminen tänä päivänä on kuitenkin yhä enemmän taitoa toimia erilaisten ihmisten kanssa alati muuttuvissa tilanteissa. Se on luovuutta ja joustavuutta, sosiaalisten tilanteiden lukutaitoa ja sitä, että opimme tunnistamaan niitä yhdessä toimimisen tapoja, jotka johtavat meidät hyviin lopputuloksiin. Nämä oppimaan oppimisen taidot, eli säätely- ja metakognitiiviset taidot (Järvelä, Järvenoja, \& Veermans 2008; Hurme, Merenluoto \& Järvelä 2009) ovat tulleet ja tulevat jatkuvasti yhä keskeisimmiksi taidoiksi elinikäisen oppimisemme poluilla.

Tämä artikkeli esittää uuden lähestymistavan yhteisöllisen oppimisen oppimiseen ja strategisesti tehokkaan yhteistoiminnan harjoittamiseen peliympäristöjen avulla. Artikkeli pohjautuu väitöstut- 
kimukseeni (Bluemink 2011), jossa olen tarkastellut mahdollisuuksia rikastaa yhteisöllistä oppimista pedagogisesti vaiheistettujen monenpelaajan virtuaalipelien kautta. Aihe kuuluu tietokonetuetun yhteisöllisen oppimisen (engl. CSCL) tutkimuksen viitekehykseen (Dillenbourg, Järvelä, \& Fischer 2009). Virtuaalisuus mahdollistaa myös fyysisesti hajautettujen tiimien pelaamisen samassa peliympäristössä yhtäaikaisesti luoden näin vahvan jaetun tilan osallistujien välille. Tämän päivän työn tekijät tarvitsevat sosiaalista tukea, eivät pelkästään teknologisia välineitä työn sisältöihin liittyvien ongelmien ja asioiden hoitamiseksi. Yhteys toisiin voi olla teknisesti auki, kuten avoinna oleva puhelu, jossa kukaan ei kuitenkaan puhu. Siksi tarvitaankin uusia tulokulmia oppimisen ja teknologian yhtymäkohtiin tiimien sosiaalisen ja emotionaalisen yhteyden rakentamiseksi ja ylläpitämiseksi.

\section{YHTEISÖLLISEN OPPIMISEN HYÖDYISTÄ}

Perinteinen käsityksemme oppimisesta tuo mieliimme luento-opetuksen, joka pohjautuu ajatukseen tiedonsiirrosta. Tieto nähdään palasina, jotka ovat siirrettävissä toisille kertomalla (Sawyer 2006). Luentotilanteessa tieto on luennoitsijalla, sen tuottajalla, ja kuulijat ovat ikäänkuin tiedon kuluttajia kuunnellessaan. Oppimisen tutkijat ovat kuitenkin nykyisin yksimielisiä siitä, että tieto ei useinkaan niin vaan siirry. On huomattu, että uuden tiedon omaksuminen on helpompaa, kun sitä voi käsitellä ja siitä voi keskustella yhdessä toisten kanssa (Dillenbourg 1999; Stahl 2006). Jos jotakin asiaa ei ymmärrä, voi kysyä apua ja pyytää toista selittämään asian uudella tavalla. Tällä tavoin sekä kysyjä että vastaaja ovat aktiivisia tiedon tuottajia, eivätkä enää tiedon vastaanottajia, kuluttajia. Kun keskustelua voidaan jatkaa niin kauan, että jokainen tilanteen osapuoli pääsee jyvälle käsiteltävästä asiasta, osallistujien välille syntyy myös yhteinen jaettu käsitys sekä asiasta että tilanteesta, jossa tuota tietoa on yhdessä rakennettu (Baker, Hansen, Joiner \& Traum 1999).

Tästä on kyse yhteisöllisessä oppimisessa. Sen on huomattu olevan oppimisen kannalta hyödyllistä monellakin tasolla. Yhdessä toimiessa on ensinnäkin käytettävissä enemmän tietoa ja näkökulmia ja tämän vuoksi todennäköisyys siitä, että päädytään oikeaan tai hyvään toimintatapaan ja lopputulemaan, on suurempi (Dillenbourg 1999). Toisekseen, useat tutkimukset ovat osoittaneet, että yhdessä toimiminen on oppimisen kannalta hyödyllistä siitä syystä, että yhteisöllinen tilanne käynnistää yksilöissä sellaisia toimintoja, jotka on todettu oppimisen kannalta erittäin keskeisiksi (Barnes \& Todd 1977). Näitä toimintoja ovat esimerkiksi selittäminen, avun antaminen ja vastaanottaminen, kysyminen ja ehdottaminen (Webb \& Mastergeorge 2003; Hakkarainen 2009). On huomattu, että yksilön ryhtyessä selittämään omia havaintojaan, näkökulmiaan ja tietoaan, hän samalla ulkoistaa omaa ajatteluaan ja uudelleenjärjestää omaa tietorakennettaan. Kolmantena tasona yhteisöllisen oppimisen hyötyjä pohdittaessa voidaan erottaa toimintatapoihin ja niin sanottuun oppimaan oppimisen taso ja tavat harjoittaa älykkyyttä. Kasvatuspsykologian professori Jerome Bruner (1996) on kirjoittanut yhdessä kirjoistaan, miten mahdollisuus voittaa fysiikan Nobel-palkinto kasvaa merkittävästi, jos pääsee työskentelemään laboratorioon, jossa joku on jo voittanut kyseisen palkinnon. Tämä ei selity pelkästään sillä, että korkea-arvoisessa seurassa tulokkaankin status nousee ja hän saa siitä nostetta, vaan nimenomaan sillä, että hän pääsee työskentelemään osaksi yhteisöä, jolla on erityinen tapa toimia ja harjoittaa älykkyyttä. Keskeistä on päästä yhteisen työskentelyn kautta näkemään ja kokemaan tehokkaat tavat ratkaista ongelmia, lukea ja kirjoittaa sekä jakaa tietoa arkipäivän työssä.

Yhteisöllisen oppimisen tutkimus on kuitenkin osoittanut, että yhteisöllinen toiminta ja sen myötä oppiminen ei ole itsestäänselvyys. Ryhmä ei aina onnistu paremmin, kuin yksilö yksin vastaavassa tilanteessa olisi onnistunut (Dillenbourg 2006). Jokaisella meistä on kokemuksia tilanteista, joissa vuorovaikutus ei jakaudu tasaisesti osallisten kesken, vaan osa ihmisistä tuntuu tietävän paremmin ja olevan myös paljon äänessä. Joissain tilanteissa asiat ovatkin hoidettavissa siten, että yksi keskittyy puhumiseen ja toinen tekemiseen. Tilanteissa, joissa jokaiselta kysytään ja jokaista kuullaan, tehdään kuitenkin samalla jokaisesta osallistujia ja yhteisen todellisuuden rakentajia (Gresalfi, Martin, Hand, \& Greeno 2009; 
Prichard 2002). Kun kaikilla on mahdollisuus osallistua tasapuolisesti, luodaan myös paremmat mahdollisuudet jaetun ymmärryksen syntyyn. Juuri jaetun ymmärryksen rakentaminen yhdessä on yhteisöllisen oppimisen ytimessä (Cherubini, van der Pol, \& Dillenbourg 2005). Useat oppimisen tutkimukset ovat osoittaneet, että ihmisten välinen sosiaalinen vuorovaikutus, jossa pyrkimyksenä on vastavuoroisen ymmärryksen rakentaminen, auttaa yksilöitä oppimaan (mm. Greeno 2006; Hakkarainen 2009). Yhteisöllistä oppimista voitaisiinkin kutsua yhteisen pohjan ja jaetun ymmärryksen rakentamiseksi, josta parhaimmillaan seuraa se, että yksilöt oppivat, eli heidän käsityksensä asioista muuttuvat ja lisääntyvät (Baker, Hansen, Joiner \& Traum 1999).

\section{VUOROVAIKUTUKSEN TUKEMINEN TEKNOLOGIAN AVULLA}

Kaikki vuorovaikutus ei kuitenkaan välttämättä johda oppimiseen. Tämän vuoksi tietokonetuetun yhteisöllisen oppimisen tutkimuslinjassa keskeisenä tavoitteena onkin ollut lisätä oppimisen kannalta hyödyllisten sosiaalisten vuorovaikutustilanteiden määrää ja laatua teknologian avulla (Dillenbourg, Järvelä, \& Fischer 2009; Barab 2003). Väitöstutkimukseni ensimmäisessä osatutkimuksessa tarkastelin yliopisto-opiskelijoiden kielenoppimista verkkooppimisympäristössä (Bluemink \& Järvelä 2003). Luokanopettajaopiskelijat keskustelivat saman alan opiskelijoiden kanssa opetusharjoittelussa saamistaan kokemuksista amerikkalaisten ja englantilaisten opiskelijoiden kanssa. Verkko-oppimisympäristöt olivat 2000-luvun vaihteessa monimuoto-opetuksen kärkeä tarjoten osallistujille mahdollisuuden oppia, ainakin teoriassa, missä ja milloin vain. Yhteisöllisen toiminnan tukemiseksi ja teknologian tuomiseksi luontevaksi osaksi kursseja ja koulutuksia kehitettiin pedagogisia malleja. Mallien keskeisenä tavoitteena oli jaksottaa toimintaa ja luoda puitteet laadukkaan sosiaalisen vuorovaikutuksen aikaansaamiseksi. Suomen Akatemian laajemmissa tutkimushankkeissa tekemämme tutkimukset kuitenkin osoittivat, että tekstipohjaiset verkko-oppimisympäristöt eivät tukeneet osallistujien välistä vuorovaikutusta parhaalla mahdollisella tavalla (Mäkitalo 2006; Arvaja 2005).
Verkkokeskustelut eivät läheskään aina johtaneet vastavuoroisiin viestiketjuihin ja kommenttien laatu ja määrä vaihtelivat (Järvelä \& Häkkinen 2002). Yhteiseen kurssiin sitoutuminen vaati osallistujilta ponnisteluja, vaikka oppimista pyrittiinkin auttamaan järjestämällä mm. paikallisia luokkahuonekeskusteluja verkkotyöskentelyn tueksi.

Syntyi ajatus kokeilla visuaalisia ja virtuaalisia peliympäristöjä yhteisöllisen oppimisen ympäristöinä. Väitöstutkimukseni toinen ja kolmas osatutkimus (Bluemink \& Järvelä 2011; Bluemink, Hämäläinen, Manninen \& Järvelä 2010; Bluemink \& Leinonen 2011) keskittyi tarkastelemaan yhteisöllisen oppimisen rikastamista ja tukemista peliympäristöjen avulla. Pelissä osallistujat toimivat virtuaalisen ihmishahmon, avatar-hahmon, välityksellä samassa kolmiulotteisessa ja erittäin todentuntuisessa maailmassa muiden ihmishahmojen kanssa keskustellen samalla mikrofonien ja kuulokkeiden välityksellä. Yhdessä pelisuunnittelijoiden kanssa rakensimme pelimaailmaan tehtäviä, joita osallistujat ratkaisivat tunnin kaksi kestävien pelisessioiden aikana. Tutkimuksissa käytetyissä peliympäristöissä olevat tehtävät eivät vaatineet erityistä sisältöosaamista, ja niissä piti esimerkiksi lähettää yhdessä oikea sarja raketteja taivaalle tai ohjata toista hakemaan mehiläispesiä tynnyri päässä. Pelaajalle peli näyttäytyi hauskana sosiaalisena toimintaseikkailuna, jossa tavoitteena oli paeta yhdessä vankilasaarelta.

Tehtävien taustalle suunniteltiin yhteisöllisen oppimisen teorioista nousevia teemoja. Käytännössä tehtävät rakennettiin siten, että tehtävän taustalla oleva pedagoginen "skripti", vaiheistus, toteutui osallistujien pelatessa. Teoreettisia teemoja olivat esimerkiksi selittäminen (Roscoe \& Chi 2008), toiminnan koordinointi (Barron 2000), tiedon jakaminen (Teasley \& Roschelle 1993) ja perspektiivinotto (Selman 1980). Pelitilanteet rakennettiin sellaisiksi, että ne luonnostaan johtivat osallistujat selittämään toisille havainnoistaan ja tiedoistaan, koordinoimaan ryhmän toimintaa tehtävän ratkaisemiseksi ja katsomaan asioita toisten näkökulmasta. Osallistumisen tasapuolisuuden lisäämiseksi pelaajien välille rakennettiin mm. tiedollista riippuvuutta antamalla eri pelaajille eri tietoja, jolloin jokaisen piti osallistua yhtei- 
seen toimintaan (Bluemink, Hämäläinen, Manninen \& Järvelä 2010). Näin ryhmän toimintaa pelissä voitiin ikään kuin ohjelmoida laukaisemaan oppimisen kannalta keskeisiä toimintoja.

\section{MITÄ PELIN AIKANA TAPAHTUU?}

Analysoin peliaineistoja sekä mikro- että makrotasoilla. Ensimmäisen peliaineiston tarkemmat mikrotason analyysit videoidusta pienryhmän keskustelusta puheenvuoro puheenvuorolta tein sisällönanalyysin keinoin luokittelemalla jokaisen pelinaikaisen keskustelun puheenvuoron kategorioihin (Bluemink \& Järvelä 2011). Aineistoa kerättiin yhteensä kuudelta neljän hengen ryhmältä ja jokaisen ryhmän peli kesti keskimäärin tunnin. Analysoitavia puheenvuoroja kertyi reilut 4500, joista suurin osa oli sisältötoteamuksia (26\%), kysymyksiä (22\%), ohjeistuksia (19\%) ja lyhyitä kuittauksia (19\%) edeltäviin puheenvuoroihin.

Havainnollistan aineistoesimerkkien kautta pelin aikaisen keskustelun luonnetta. Ensimmäisessä esimerkissä yliopisto-opiskelijoista satunnaisesti koottu ryhmä on aivan pelin alussa jokainen omassa sellissään, joista he eivät pääse ulos. Sellien ovet avautuvat aikalukolla, jonka tarkoituksena on laukaista keskustelu osallistujien välillä. Puheenvuoron jälkeen näkyy suluissa kategoria, mihin puheenvuorot analyysissä jaoteltiin.

Timo: Pikku kopissa oon täällä ja ovi on lukossa (sisältötoteamus)

Janne: Vähän masentaa (sosiaalinen toteamus)

Jenni: (naurahdus) Ahistaa (sosiaalinen

toteamus)

Janne: joo (kuittaus)

Timo: onko perga pergamentissä mitään tolkkua (kysymys)

Janne: Emmä [ymmärrä siitä yhtään mitään (sisältötoteamus)

Kaisu: siin on jotain ohjeita] (sisältötoteamus)

Janne: Emmä kyllä tajua siitä yhtään mitään (sisältötoteamus)

Jenni: Ollaanko me kaikki eri kopissa kun ei täältä kettään näy? (kysymys)

Timo: joo (kuittaus)
Janne: ollaan me (kuittaus)

Kaisu: Tääl on ikkuna (sisältötoteamus)

Janne: Jotenkin tää ovi nyt kyllä täytyy saada auki (ehdotus)

Timo: Ei hyppäämällä pääse (sisältötoteamus)

Janne: joo ei, ei se ihan (kuittaus)

Toisessa aineistoesimerkissä toinen ryhmä on aloittamassa tehtävän ratkaisemista, jossa heidän täytyy hakea mehiläispesiä aidatulta alueelta. Alueella voi liikkua pelkästään tynnyri suojanaan, joten toisten täytyy ohjata tynnyrissä pimennossa olevia liikkumaan oikeaan suuntaan. Pelaajat liikkuvat siis keskustellessaan samanaikaisesti oman avatar-hahmonsa kautta peliympäristössä havainnoiden vihjeitä ja alueita.

Mirja: Missä sää oot? (kysymys)

Juha: Täällä tynnyrin sisällä (sisältötoteamus)

Mirja: Ookko nää höperö? (kysymys)

Maikki: Millä noita tynnyreitä vois kannella, oliko teillä joku idea (kysymys)

Siri: (epäselvä)ekkö pääsis hakkeen ... (kysymys)

Juha: (epäselvä) eiku mää kävelen ite nytte, hei teijän pitää ohjata mua (käsky)

Siri: Aha (kuittaus)

Juha: mää oon täällä tynnyrissä nytte mä en tiiä yhtä̈n mihin suuntaan, mihin suuntaan mun pitää lähtee (sisältötoteamus)

Mirja: Etkö sää pääse pois siitä (kysymys)

Juha: Ei pääsen pois mutta mää tällähän pääsee sinne tuonne mehiläisten luo (ehdotus)

Siri: Ampiaispesähän? (kysymys)

Juha: Niin (kuittaus)

Puheenvuorotason analysointi osoitti, että osallistujat keskustelivat aktiivisesti lyhyin puheenvuoroin ja jatkuvasti. Kategoriat olivat oppimiseen yhdistettäviä elementtejä, mutta eivät kuitenkaan vielä kertoneet, oliko ryhmän toiminta jaettua, toimivatko kaikki yhdessä. Tämän vuoksi jatkoin analysointia makrotasolla keskittymällä muutaman minuutin pätkiin tehtävien ratkaisun kannalta oleellisilla hetkillä, juuri ennen tehtävien ratkeamista (Barron, 2003). Katsoin hetki 
hetkeltä, mitä kukin ryhmän jäsen teki ja sanoi ja reagoivatko he toistensa kysymyksiin ja huomioihin.

Analyysi osoitti, että tilanteen salliessa virtuaalinen peliympäristö houkutteli useita pelaajia yksilösuorituksiin ja jatkuvaan juoksenteluun alueella. Kaikki pelitilanteet eivät olleet jaettuja ja yhdessä ratkaistuja (Bluemink \& Järvelä 2011). Näiden havaintojen pohjalta toisen peliversion tehtävistä pyrittiin tekemään sellaisia, että jokaisen osallistumista vaadittiin tehtävien ratkaisemiseksi. Ylenpalttista juoksentelua vähennettiin mm. avaamalla yksi tehtäväkenttä kerrallaan, jolloin pelaajat pysyivät myös luontevasti lähellä toisiaan. Keskeisenä tavoitteena tehtävien suunnittelussa olikin pitää osallistujat yhdessä ja tehdä yksin eteneminen mahdottomaksi.

\section{TIIMIN YHTEISTOIMINNAN JÄLJILLÄ}

Toinen peliaineisto kerättiin työelämässä olevilta aikuisilta, jotka osallistuivat järjestämäämme puolen päivän mittaiseen pelieksperimenttiin. Suurimmalla osalla neljän hengen ryhmissä pelanneista osallistujista ei ollut aiempaa pelikokemusta. Yhteensä kuudesta ryhmästä kerätyssä aineistossa kaksi ryhmistä oli olemassa olevia tiimejä ja neljä ryhmää koostui satunnaisesti kootuista toisilleen aiemmin tuntemattomista henkilöistä.

Pelikokemuksen reflektoinnilla eli pelinaikaisen toiminnan käsittelyllä pelin jälkeen on ratkaiseva merkitys syvempien oppimisvaikutusten saavuttamiseksi (Kneser \& Ploetzner 2001). Pelaamisen kautta ryhmälle rakentuu yhteinen sosiaalinen kokemus, joka muodostaa hedelmällistä raaka-ainetta oman toiminnan analysoimiseksi. Tutkimustilanteessa reflektiona toimivat noin puolen tunnin yksilöhaastattelut välittömästi pelin päätyttyä. Haastattelijan kysymykset, kuten esimerkiksi "Miten toimitte tuossa tehtävässä?" tai "Miten toiminnan suunnittelu ilmeni pelin aikana?" auttoivat osallistujia miettimään peliä pintaa syvemmältä.

Kuvaan seuraavassa yksilöhaastatteluaineiston esimerkkien kautta pelaajien ajatuksia pelin jälkeen. Ensimmäisessä aineistoesimerkissä yksi osallistuja kuvaa, miten kolmas tehtävä, jossa heidän pitää valmistaa öljyä, ohjaa heitä miettimään tarkemmin ja toimimaan yhdessä. Useille osallistujille tyypilliseen tapaan tehtävää ratkaistiin ensin yrittämällä eri vaihtoehtoja, mutta peli saa osallistujat keskustelemaan ja miettimään vaihtoehtoisia toimintatapoja.

"No tää jäi esimerkiksi tämä patahomma [Joo] Missä laitettiin sinne niitä niin... Siinä aluksi vaan nakeltiin niitä sinne ja sitten se sanoi, että yksi on väärin ja ei me siinä vaiheessa vielä tajuttu mittään että se yksi oli väärin. Sitten me alettiin niin kun nakkeleen sinne muuta ja sitten oli yhtäkkiä kaikki väärin. Tai yks vissiin oli oikein mutta... Se oli sillain, että sitten alettiin keskustelemaan että mitä siihen vois tarvia ja sitten ei ne kovin järkeen käypiä ollut mitä sinne piti nakella (naurahtaa), mutta tuota kuitenkin päästiin yhteiseen lopputulokseen niin se meni sitten oikein [Joo]. Että ei siinä varmaan yksin ois kovin helpolla, ehkä." (Pekka, 25-vuotias myyntineuvottelija)

Toisessa ryhmässä pelannut osallistuja kuvaa puolestaan miten hän koki saman tehtävän jälkeenpäin. Haastattelupätkässä korostuu kaikkien osallistujien mukana olon tärkeys, koska ilman kaikkien panosta eteneminen ei onnistu. Haastateltava myös reflektoi kokemuksiaan arkipäivän työhön ja tilanteisiin.

"Että kaikkia tarvitaan, että kukaan meistä ei niin kun voi yksin tehdä mitään. Vaan se että me tarvitaan se koko porukka siihen matkaan että me päästään. Se musta oli hyvä että jos kaikki ei ollut mukana, niin sitte ei kukkaan päässyt mihinkään. Että siihen tarvittiin se koko jengi matkaan, niin se on työyhteisössä hirveen tärkeetä. Se on kans semmoinen oivallus että tuota niin niin... me voidaan sitten aatella että tuo yks jää tuonne että jos se ei oo kerennyt tai sitä ei huvita tai se ei oo halunnut niin meidän pitäis kuitenkin saada se matkaan sieltä." (Liisa, 46-vuotias, johtavassa asemassa)

Toisessa ryhmässä pelannut kolmas osallistuja kertoo, miten ryhmän jäsenten erilainen lähtötaso pelaamisessa vaikutti pelin aikana. Hän kuvaa, miten aluksi muut pelaajat seurasivat kokeneempaa osallistujaa hänen halutessa johtaa toimintaa. Peli ei kuitenkaan kannusta yksilösuorituksiin, eivätkä tehtävät toisaalta noudata viihdepelien toimintamalleja, joten 
kaikkien oli "päästävä samaan tiedon tasoon", kuten haastateltava asian kuvaa. Tällä tavoin pelin tehtävät ikään kuin pakottavat osallistujat jaetun ymmärryksen rakentamiseen, joka vie aikaa, mutta osallistaa jokaisen.

"Ehkä siinä oli vähän semmoista, että kun jos yks on ... ö̈̈̈... selkeesti enemmän selvillä asioista, [Hmm] niin sitten helposti annetaan niin ku että hän selvittää kaikki. Mutta se ei ehkä ollut nyt sitten, varsinkin tässä nyt haettiin sitä että kaikkien pitäis suunnilleen päästä sille samalle tasolle niin sitten se homma ratkeaa. Niin ehkä siinä niin kun alussa oli sitä että lähti takas siihen suuntaan, että tuntui, että kerran yks tietää ja haluaa tehä, niin se vettää sitä juttua ja muut tullee perässä niin ku lampaat. Mutta sitten ei onnistunut, niin sitten oli kaikkien pakko siihen tuota niin niin ... lähtä niin ku tekemään, elikkä sitten myöskin päästä sille samalle tiedon tasolle että se onnistuu se homman tekeminen." (Heidi, 33-vuotias, oppilaitoksen koordinaattori)

Viimeisessä esimerkissä osallistuja reflektoiden kertoo omasta toiminnastaan pelin aikana ja linkittää tapaansa toimia myös arkipäivän tilanteissa. Pelistä muodostui vahva sosiaalinen kokemus, josta riitti paljon puhuttavaa haastatteluvaiheessa. Myös muut osallistujat vertasivat omaa toimintaa ja tiimin toimintaa arjen tilanteisiin. Pelin avulla osallistujia voidaankin harjoittaa perspektiivinottoon suunnittelemalla pelin jälkeistä toimintaa sitä tukevaksi.

Mä hoksaan nyt että yleensäkin mun tiimitapa toimia on ... mä oon aina sellanen, että mä pikkasen kuulosten. Sitä mä tein alussa. Ja annan ... katon että miten mä pysyn jossakin vaiheessa viimeistään olemaan apuna ja näin päin pois. Sitte siinä kun me saatiin ne työkalut sieltä ja päästiin niitä koiria pakoon niin sitten porukat rupes vielä, että no rakennetaan näitä aitoja. Niin mää sanoin, ettei enää yhtä̈n aitoja, että nyt nopeesti sisälle (naurua) Että sitten kun määrätyllä lailla saa semmosen... hoksaa mistä on kysymys niin pyrkii niin että nyt pitää mennä sisälle... (naurua) (Leena, 42-vuotias, julkisen sektorin asiantuntijatehtävissä)

\section{POHDINTA}

Tutkimuksissa tarkastelluissa peleissä pelaaminen tempaisi sekä korkeakouluopiskelijat että yrityksistä ja organisaatioista tulleet osallistujat mukaansa. Keskusteleminen ja ongelmien ratkaiseminen yhdessä samanaikaisesti avataren kautta toimien vaati jokaiselta jakamattoman huomion (Bluemink \& Leinonen 2011). Pelieksperimenttien havainnointi osoitti, että pelitehtävien avulla oli mahdollista tukea ryhmän yhteisöllistä toimintaa ja jaetun ymmärryksen rakentamista osallistujille mielekkäällä tavalla.

Aiemmat yhteisöllisen oppimisen tutkimukset ovat osoittaneet, että kaikissa yhteisöllisissä ongelmanratkaisutilanteissa on läsnä sekä sisältötaso eli itse asiaan liittyvä taso että suhdetoiminnan taso eli sosiaaliseen vuorovaikutukseen liittyvä taso (Teasley \& Roschelle 1993; Barron 2003). Tutkimukseni perusteella monenpelaajan virtuaalipeliympäristössä sisältö ja suhdetoiminnan tasojen lisäksi on löydettävissä kolmas, virtuaalihahmon eli avataren kautta toimimiseen liittyvä taso. Käytännössä pelaajan on pelatessaan yhtä aikaa sekä liikuttava ja toimittava ympäristössä avataren kautta että keskusteltava muiden kanssa ongelmia ratkoen. Avataret lisäävät vuorovaikutteisuutta (Falloon 2010), koska niiden kautta pelaajat voivat mm. seurata toisten osallistujien toimintaa ja liikkeitä, auttaa toisia löytämään oikealle paikalle tehtävän suorittamista varten ja hakea huomiota vaikkapa hyppimällä. Peliympäristössä kaikki vuorovaikutus ei siis pohjaudu keskusteluun ja toisaalta jaettua ymmärrystä voi testata hetimiten tehtäviä suoritettaessa. Kaikille ei aina synny keskustellessa samaa käsitystä asiasta, ja tämä paljastuu, kun tehtävää ryhdytään suorittamaan.

Pedagogisesti suunnitellulla monenpelaajan pelillä on mahdollista harjoittaa osallistujia strategisesti tehokkaan yhteistyön elementeistä. Pelin avulla on mahdollista tuottaa jokaiselle ryhmän jäsenelle osallistumisen ja toimijuuden kokemuksia, joita voi hyödyntää arjen työtilanteissa. Toimijuuden tutkimuksella on pitkät perinteet eri toimintaympäristöissä kuin pelimaailmoissa, (Bandura, 2001) mutta on nähtävissä, että peliympäristöjen suunnittelun kautta toimijuuden merkitystä olisi mahdollista harjoittaa helposti omaksuttavalla tavalla. Tavoiteltaessa 
parempaa tiimityötä keskeistä on oppia tarkastelemaan omaa toimintaansa lintuperspektiivistä ja tulla tietoiseksi omasta ja ryhmän tavoista toimia haastavissa ongelmanratkaisutilanteissa. Reflektointitaito on välttämätöntä syvälliselle ja jatkuvalle oppimiselle (Kneser \& Ploetzner 2001).

Reflektointitaidolla on myös iso merkitys jo aiemmin mainittuun oppimisen siirtovaikutukseen eli siihen onko pelikokemuksella lopulta vaikutusta arjen opiskelu- tai työtilanteisiin. Tämä on tunnistettavissa myös alan tutkimuksen seuraavaksi haasteeksi (Gee 2006; Sawyer 2007), ja siitä on toistaiseksi hyvin vähän, jos lainkaan, oppimisen näkökulmasta tehtyjä tutkimuksia. Koska väitöstutkimukseni kaltaiset, empiiriset ja laadullisin tutkimusmenetelmin analysoidut pelitutkimuksetkin ovat vielä verrattain uusi asia, pelaamisen pitkäaikaisia vaikutuksia aidoissa työympäristöissä ei ole vielä ehditty tutkia. Jotta tulevaisuuden pelejä voidaan kehittää vastaamaan yhä paremmin työn ja hajautetun työn tuomiin haasteisiin, ovat aidot työympäristöt tutkimukselle keskeisiä tutkimus ja kehittämisalustoja.

Hyötypelien käytölle ja soveltamiselle voidaan nähdä lähes rajattomia mahdollisuuksia. Pelejä voidaan käyttää sekä perinteisten, samassa tilassa työskentelevien tiimien tukena että verkossa hajautettujen tiimien yhteisenä virtuaalitilana. Yhdistämällä pelaamista muuhun koulutus- ja kehitystoimintaan on mahdollista rikastaa perinteisiä toimintatapoja. Näen, että suurin koulutuksellinen lupaus peliympäristöjen hyödyntämiseen liittyy pelien kokemuksellisuuteen ja omakohtaisen osallistumisen kautta oppimiseen. Parhaimmillaan pelikokemuksen kautta voidaan lisätä tietoisuutta yksilöiden toimijuudesta käytännössä siitä, että kaikki yhteisöt ovat oman toimintansa tuloksia ja samalla käsikirjoittajia.

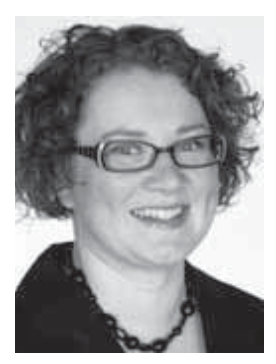

Johanna Bluemink

KT, TeamingStream Oy, Oulu Kirjoittaja väitteli Oulun yliopiston kasvatustieteellisessä tiedekunnassa 27.5.2011.

\section{LÄHTEET}

Arvaja, M. (2005). Collaborative knowledge construction in authentic school contexts. (Unpublished doctoral dissertation). University of Jyväskylä, Finnish Institute for educational research, Jyväskylä, Finland.

Baker, M., Hansen, T., Joiner, R., \& Traum, D. (1999). The role of grounding in collaborative learning tasks. In P. Dillenbourg (Ed.), Collaborative learning: Cognitive and computational approaches (31-64). Amsterdam: Pergamon.

Bandura, A. (2001). Social cognitive theory: an agentic perspective. Annual Review of Psychology 52, 1-26. Barab, S. (2003). An introduction to the special issue: designing for virtual communities in the service of learning. The Information Society 19, 197-201.

Barnes, D., \& Todd, F. (1977). Communication and learning in small groups. London: Routledge \& Kegan Paul.

Barron B. (2000). Achieving coordination in collaborative problem-solving groups. The Journal of the Learning Sciences 9 (4), 403-436.

Barron, B., (2003). When smart groups fail. The Journal of Learning Sciences, 12 (3), 307-359.

Bluemink, J. (2011). Virtually face to face: Enriching collaborative learning through multiplayer games. (Unpublished doctoral dissertation). University of Oulu, Faculty of education, Oulu, Finland.

Bluemink, J., Hämäläinen, R., Manninen, T., \& Järvelä, S. (2010). Group-level analysis on multiplayer game collaboration: How do the individuals shape the group interaction? Interactive Learning Environments 18(4), 365-383.

Bluemink, J. \& Järvelä, S. (2003). Face-to-face encounters as contextual support for Web-based discussions in a teacher education course. The Internet and Higher Education, 7, 199-215.

Bluemink, J. \& Järvelä, S. (2011). Elements of collaborative discussion and shared problemsolving in a voice-enhanced multiplayer game. Journal of Interactive Learning Research, 22(1), 23-50.

Bluemink, J. \& Leinonen, P. (2011). How the distributed teams manage aspects of collaborative game activity in the context of voice-enhanced multiplayer-game. Manuscript.

Bransford, J., Barron, B., Pea, R., Meltzoff, A., Kuhl, P., Bell, P., et al. (2006). Foundations and opportunities for a interdisciplinary science of learning. In K. Sawyer (Ed.), The Cambridge handbook of the learning sciences (19-34). New York, NY: Cambridge University Press. 
Bruner, J. (1996). The culture of education. Cambridge, Mass.: Harvard University Press.

Cherubini, M., van der Pol, J., \& Dillenbourg, P. (July, 2005). Grounding is not shared understanding: Distinguishing grounding at an utterance and knowledge level. Paper presented at CONTEXT '05, the Fifth International and Interdisciplinary Conference on Modelling and Using Context, Paris, France.

Dillenbourg, P. (1999). Introduction: what do you mean by "collaborative learning"? In P. Dillenbourg (Ed.) Collaborative learning: cognitive and computational approaches (1-19). Amsterdam: Pergamon.

Dillenbourg, P. (2006). The solo/duo gap. Computers in Human Behavior, 22, 155-159.

Dillenbourg, P., Järvelä, S., \& Fischer, F. (2009). The evolution of research on computer-supported collaborative learning: from design to orchestration. In N. Balacheff, S. Ludvigsen, T. de Jong, T., A. Lazonder \& S. Barnes (Eds.) Technology-enhanced learning: principles and products (3-19). Springer Science + Business Media B. V.

Falloon, G. (2010). Using avatars and virtual environments in learning: What do they have to offer? British Journal of Educational Technology, 41, 108-122.

Gee, J. P. (2006). Are video games good for learning? Digital Kompetanse, 3, 172-183.

Gresalfi, M., Martin, T., Hand, V., \& Greeno, J. (2009). Constructing competence: an analysis of student participation in the activity systems of mathematics classrooms. Educational Studies in Mathematics, 70, 49-70.

Greeno, J. (2006). Learning in activity. In R. K. Sawyer (Ed.), The Cambridge Handbook of the Learning Sciences (pp. 79-96). New York: Cambridge University Press.

Hakkarainen, K. (2009). Three generations of technology-enhanced learning. British Journal of Educational Technology, 40, 879-888.

Hurme, T-R, Merenluoto, K., \& Järvelä, S. (2009). Socially shared metacognition of pre-service primary teachers in a computer-supported mathematics course and their feelings of task difficulty: a case study. Educational Research and Evaluation, 15, 503-524.

Järvelä, S., \& Häkkinen, P. (2002). Web-based cases in teaching and learning - the quality of discussions and a stage of perspective taking in asynchronous communication. Interactive Learning Environments, 10, 1-22.

Järvelä, S., Järvenoja, H., \& Veermans, M. (2008). Understanding dynamics of motivation in socially shared learning. International Journal of Educational Research,47(1), 122-135.
Kneser, C., Ploetzner, R. (2001). Collaboration on the basis of complementary domain knowledge: observed dialogue structures and their relation to learning success. Learning and Instruction, 11, 53-83.

Mäkitalo, K. (2006). Interaction in online learning environments: How to support collaborative activities in higher education settings. Jyväskylä University, Koulutuksen tutkimuslaitoksen Tutkimuksia -sarja, 18.

Prichard, J. (2002). Teamwork and collaborative learning. Does team-skills training enhance educational outcomes? (Unpublished doctoral dissertation). University of Southampton, UK.

Prins, S. (2010). From competition to collaboration: critical challenges and dynamics in multiparty collaboration. Journal of Applied Behavioral Science 46 (3).

Roscoe, R., \& Chi, M. (2008). Tutor learning: the role of explaining and responding to questions. Instructional Science, 36, 321-350.

Salas, E., Rosen, M., Burke, C., Goodwin, G., \& Fiore, S. (2006). The making of a dream team: when experts teams do best. In K. Ericsson, N. Charness, P. Feltovich, R. Hoffman (Eds.), The Cambridge handbook of expertise and expert performance (439-453). New York: Cambridge University Press.

Sawyer, R. (2006). Analysing collaborative discourse. In R. Sawyer (Ed.), The Cambridge handbook of the learning sciences. (187-204). New York: Cambridge University Press.

Sawyer, B. (2007). Serious games: broadening games impact beyond entertainment. Computer Graphics Forum, 26(3), xviii.

Selman, R. (1980). The growth of interpersonal understanding. New York: Academic Press.

Stahl, G. (2006). Group cognition: computer support for building collaborative knowledge. Cambridge, MA: MIT Press.

Teasley, S. \& Rochelle, J. (1993). Constructing a joint problem space: the computer as a tool for sharing knowledge. In P. Lajoie \& S. J. Derry (Eds.), Computers as cognitive tools (229-257). Hillsdale (NJ): Lawrence Erlbaum.

Webb N., \& Mastergeorge A. (2003). Promoting effective helping behavior in peer-directed groups. International Journal of Educational Research, 39. 73-97.

\section{Artikkeli on toteutettu Ella ja Georg Ehrnroothin} säätiön apurahan turvin.

Artikkeli saapui toimitukseen 8.8.2011. Se hyväksyttiin julkaistavaksi 1.11.2011. 